\title{
Synergistic Effect Between Curcumin (diferuloylmethane) and Radiation on Clonogenic Cell Death Independent of p53 in Prostate Cancer Cells
}

\author{
Bijaya K. Nayak ${ }^{1}$, Naveen K. Krishnegowda ${ }^{1}$, Cynthia A. Galindo ${ }^{2}$, Martin L. Meltz ${ }^{3}$ and Gregory P. Swanson * \\ ${ }^{1}$ Department of Medicine, The University of Texas Health Science Center at San Antonio, 7703 Floyd Curl Drive, San Antonio, TX, USA \\ ${ }^{2}$ Department of Urology, The University of Texas Health Science Center at San Antonio, 7703 Floyd Curl Drive, San Antonio, TX, USA \\ ${ }^{3}$ Department of Radiation Oncology, The University of Texas Health Science Center at San Antonio, 7703 Floyd Curl Drive, San Antonio, TX, USA
}

\begin{abstract}
Radiotherapy is a common treatment for prostate cancer, but failure is observed 30 to $40 \%$ of the time. It is more common in patients with abnormal p53. The phytochemical diferuloylmethane (curcumin) a naturally occurring flavinoid derived from the rhizome of Curcuma longa, shows potential radiosensitizing effects. In the present study, the effect of curcumin and radiation on cell viability, apoptosis and clonogenic cell death was examined in LNCaP (wild type p53) and PC3 (mutant p53) prostate cancer cells.

The expression of p53 and p53 target genes was examined using RNase protection assay and Western blot analysis. Cell cycle and apoptosis was evaluated by flow cytometry. Cell viability and colony formation was examined using MTT assay and clonogenic assay respectively.

The expression of p53, p21 and gadd45 increased in LNCaP cells after radiation exposure. In PC3 cells, there was no change in expression in mutant p53 after radiation or curcumin treatment. However, the expression of p21 and gadd45 increased after curcumin treatment in PC3 cells independent of p53. Curcumin induced cell growth arrest and apoptosis in both the cell lines. The cell viability and cell proliferation decreased in presence of both curcumin and radiation as compared to curcumin or radiation alone in both the cell lines. Regardless of p53 status, combination treatment with curcumin $(2.5$ to $10 \mu \mathrm{M})$ and radiation $(2 \mathrm{~Gy})$ had a synergistic effect on clonogenic cell death in both LNCaP and PC3 cells.
\end{abstract}

Conclusion: Curcumin appears to radiosensitize prostate cancer cells and may be a possible adjuvant to radiotherapy in the treatment of prostate cancers.

Keywords: Curcuma longa; Curcumin; Radiation; Clonogenic cell death; Synergy; p53; Prostate cancer

\section{Introduction}

Cancer is the second leading cause of death in the United States and prostate cancer is the most prevalent male cancer. Approximately 217,730 new cases of prostate cancer and 32,050 deaths are projected to occur in USA in 2010 (Jemal et al., 2010). Most of the prostate cancer patients are treated during the course of their illness by radiotherapy alone or as an adjuvant treatment for surgery (Swanson, 2006; Swanson et al., 2006; Thompson et al., 2006). However, failure of radiotherapy is observed in about $30-40 \%$ of prostate cancer patients (Kalkner et al., 2007; Thompson et al., 2007). The radio resistance of prostate cancer cells is a limitation of radiotherapy. The effectiveness of radiotherapy mainly depends on the molecular context of the tumor. The molecular mechanisms leading to radiosensitivity and radioresistance development remain elusive (Rosen et al., 1999; Skvortsova et al., 2008). Therefore, there is immense interest in understanding the critical determinants in radiation-induced cell killing and developing new agents for radiosensitization.

The p53 tumor suppressor protein plays an important role in radiation response and radiotherapy failure is more common in prostate cancer patients with abnormal p53 (Razoky et al., 1999; Ritter et al., 2002). p53 is activated in response to different anti-cancer agents including ionizing radiation (Levine et al., 1991; Haupt et al., 2003). Active p53 functions as a transcriptional regulator and in turn regulates its downstream genes like p21, gadd 45 , and bax, -resulting in cell growth arrest, apoptosis and cellular senescence (Nayak and Das, 2002; Fridman and Lowe, 2003). p53 is mutated or inactivated in early as well as in advanced-stage prostate cancers (Bookstein et al., 1993; Chi et al., 1994; Gumerlock et al., 1997; Stapleton et al., 1997; Downing et al., 2003). Mutant or inactive p53 may limit the effectiveness of radiotherapy in prostate cancers (Razoky et al., 1999; Ritter et al., 2002; Lehman et al., 2007). Wild-type p53 significantly increases clonogenic cell death through p53-dependent cellular senescence and apoptotic pathways in prostate cancer (Lehman et al., 2007). Therefore, if treatment could be tailored as to abrogate the need for an intact p53, the results of radiotherapy in prostate cancer could be improved. There are agents that act on the molecular level that may make this possible.

Curcumin (diferuloylmethane) (Figure 1) is a polyphenol derived from the rhizome of the turmeric plant (Curcuma longa, family Zingiberaceae). It is used as a flavoring and coloring agent, as a food preservative and in Ayurvedic medicine (Corson and Crews, 2007; Shishodia et al., 2007). It has been consumed for centuries as a dietary spice at the rate of up to $100 \mathrm{mg} / \mathrm{day}$ by people in

*Corresponding author: Gregory P. Swanson, MD, Associate Professor, Department of Radiation Oncology, The University of Texas Health Science Center at San Antonio, Floyd Curl Drive, San Antonio, TX, USA, Tel: 210-450-5699; Fax: 210-450-5085; E-mail: swansong@uthscsa.edu

Received June 29, 2010; Accepted September 17, 2010; Published September 17,2010

Citation: Nayak BK, Krishnegowda NK, Galindo CA, Meltz ML, Swanson GP (2010) Synergistic Effect Between Curcumin (diferuloylmethane) and Radiation on Clonogenic Cell Death Independent of p53 in Prostate Cancer Cells. J Cancer Sci Ther 2: 171-181. doi:10.4172/1948-5956.1000046

Copyright: @ 2010 Nayak BK, et al. This is an open-access article distributed under the terms of the Creative Commons Attribution License, which permits unrestricted use, distribution, and reproduction in any medium, provided the original author and source are credited. 
Citation: Nayak BK, Krishnegowda NK, Galindo CA, Meltz ML, Swanson GP (2010) Synergistic Effect Between Curcumin (diferuloylmethane) and Radiation on Clonogenic Cell Death Independent of p53 in Prostate Cancer Cells. J Cancer Sci Ther 2: 171-181. doi:10.4172/19485956.1000046

Asian countries (Ammon and Wahl, 1991). It is believed that lower incidence of prostate cancer in Asian countries than in Western countries may be due to differences in diet (Hebert et al., 1998; Denis et al., 1999; Hsing et al., 2000). Curcumin possesses diverse anti-inflammatory and anti-cancer properties (Kawamori et al., 1999; Aggarwal et al., 2005; Khor et al., 2006; Herman et al., 2009; Khan et al., 2010). Studies have shown that curcumin can induce apoptosis by different mechanisms, such as, by inhibiting the expression of the anti-apoptotic genes bcl-2 and bcl- $\mathrm{x}_{\mathrm{L}}$, by inhibiting AP-1 and NF$\kappa \mathrm{B}$ transcription factors (Mukhopadhyay et al., 2001; Anto et al., 2007; Shankar and Srivastava, 2007; Li et al., 2007; Jutooru et al., 2010). Preclinical, phase I and phase II clinical studies suggest that curcumin is pharmacologically safe and it is well tolerated without any toxic effects (Cheng et al., 2001, Sharma et al., 2001; Sharma et al., 2004; Dhillon et al., 2008). In the present study, we tested the hypothesis that combination of curcumin with radiation would enhance apoptosis and clonogenic cell death of prostate cancer cells independent of the p53 status.

\section{Materials and Methods}

\section{Cell lines}

The PC3 and LNCaP prostate cancer cells were purchased from ATCC. The cells were maintained in RPMI 1640 medium supplemented with $10 \%$ heat inactivated fetal bovine serum (Hyclone, Logan, UT) and $1 \%$ Penicillin/Streptomycin. The cells were maintained in T-75 tissue culture flasks with filter caps in a humidified $5 \% \mathrm{CO}_{2} / 95 \%$ air atmosphere at $37^{\circ} \mathrm{C}$.

\section{Ionizing radiation}

Cells were exposed to a 2 to $20 \mathrm{~Gy}$ dose of ${ }_{137} \mathrm{Cs}$ gamma rays (Atomic Energy of Canada/Nordion). The dose rate was $\sim 1.1 \mathrm{~Gy} /$ minute. The cells were exposed at room temperature in $100 \mathrm{~mm}$ culture dishes or in T-25 culture flasks or in 96-well plates immediately after removal from the $37^{\circ} \mathrm{C}$ incubator. The flasks were returned to the incubator immediately after the exposure.

\section{Curcumin}

Curcumin $\quad\left(\left[\mathrm{HOC}_{6} \mathrm{H}_{3}\left(\mathrm{OCH}_{3}\right) \mathrm{CH}=\mathrm{CHCO}\right]_{2} \mathrm{CH}_{2}\right) \quad$ (Figure 1) was purchased from Sigma-Aldrich (product number C7727; St. Louis, $\mathrm{MO})$. The source and country of manufacture was India. On high pressure liquid chromatograph, purity was $99 \%$ total curcuminoids and $93 \%$ curcumin. Cells were exposed to radiation ( 2 to $20 \mathrm{~Gy}$ ) alone, curcumin $(2.5$ to $20 \mu \mathrm{M})$ alone, or the combination of the two. For combination treatment, cells were treated with curcumin (2.5 to 10 $\mu \mathrm{M})$ for $2 \mathrm{hr}$ prior to radiation exposure ( $2 \mathrm{~Gy}$ ). The control for the effects of curcumin was radiation without the compound.

\section{RNAse protection assay}

Expression of p53 and p53 target genes was examined using the RNase protection assay (RPA) as previously described (Nayak and Das, 2002). The human riboprobe set containg bcl- $x_{L}, p 53$, c-fos, p21, bax, bcl-2, Mcl-1, L32, and GAPDH was used (BDBiosciences, San Jose, CA). RNA expression of L32 and GAPDH were used as

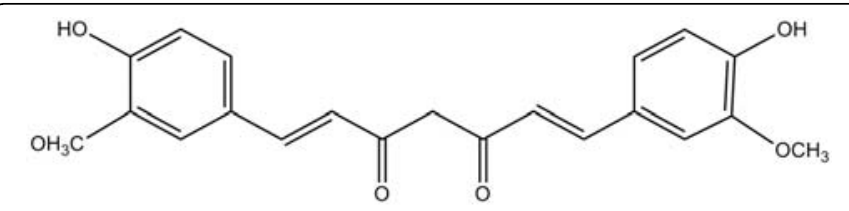

Figure 1: Chemical structure of curcumin. internal loading controls. The riboprobe set was labeled with T7 RNA polymerase in the presence of $\left[\alpha^{32} \mathrm{P}\right] \mathrm{UTP}$, and was used for RPA following the manufacturer's protocol (BDBiosciences). The gels were scanned using a Typhoon 8600 Variable Mode Imager. Quantitative assessment was carried out using Image Quant (Molecular Dynamics, Sunnyvale, CA).

\section{Western blot analysis}

In addition, expression of p53 and p21 was examined using Western blot analysis (Nayak and Das, 2002). A 50- $\mu$ g sample of the cell lysate was electrophoresed on a $10 \%$ SDS-polyacrylamide gel and transferred to a nitrocellulose membrane (Whatman Inc., Florham Park, NJ). The membrane was incubated with primary antibody [p53 (DO-1, Santa Cruz Biotechnology), p-p53-Ser15 (9284, Cell Signaling,Technology, Inc., Danvers, MA), p21 (C-19, Santa Cruz Biotechnology), bax ( sc-493, Santa Cruz Biotechnology), bcl2 (sc-492, Santa Cruz Biotechnology), actin (A1978, Sigma-Aldrich), GAPDH, sc-25778, Santa Cruz Biotechnology)] overnight at $4^{\circ} \mathrm{C}$. Actin and GAPDH were used as internal loading controls. The membrane was developed using enhanced chemiluminescence (ECL) reagents (Amersham Biosciences). Quantitation of Western blot was carried out using the Scion Image 4.03 software program.

\section{Caspase 9 assay}

Apoptosis was examined by quantifying active caspase 9 using the carboxyflourescein caspase detection kit (Biocarta, San Diego, CA). With this system, active caspases are detected in live cells through the use of a carboxyfluorescein (FAM) labeled peptide fluromethyl ketone (FMK) caspase inhibitor (FAM-Peptide-FMK). Caspase positive cells were distinguished from caspase negative cells in a Becton Dickinson FACSCalibur Flow Cytometer.

\section{Annexin $\mathrm{V}$ binding assay}

Apoptosis was also assayed using annexin V-FITC apoptosis detection kit (Calbiochem, La Jolla, CA). The cells were then stained with annexin and annexin V-positive cells were analyzed using flow cytometry.

\section{Cell cycle analysis}

Cell cycle analysis was carried out at $48 \mathrm{~h}$ post-exposure. The cells were harvested, and resuspended in PBS containing propidium iodide $(50 \mu \mathrm{g} / \mathrm{mL})$, RNase A $(500 \mu \mathrm{g} / \mathrm{mL})$, and Triton X-100 $(0.5 \%)$, and incubated in the dark for 1 hour. The cell cycle analysis was performed by flow cytometry in a Becton Dickinson FACS Calibur Flow Cytometer. The results were determined using ModFit software and reported as percentage $\mathrm{G} 1$, percentage $S$, and percentage $\mathrm{G} 2 / \mathrm{M}$ cells.

\section{MTT assay}

Cell viability was examined by using MTT [3-(4,5-dimethylthiazolyl2)-2,5-diphenyltetrazolium bromide] assay (Sigma-Aldrich). Cells were treated with 2.5 to $10 \mu \mathrm{M}$ curcumin. After 2 hours of curcumin treatment, cells were exposed to $2 \mathrm{~Gy}$ dose of ionizing radiation. The MTT assay was performed after 7 days of seeding. The cell precipitate was dissolved in $100 \mu \mathrm{L}$ of dimethyl sulfoxide and the optical density was measured at $570 \mathrm{~nm}$ using a Spectrafluor plate reader.

\section{Clonogenic assay}

PC3 $(\sim 2,000)$ and $\operatorname{LNCaP}(\sim 9,000)$ cells were seeded in $100 \mathrm{~mm}$ tissue culture dishes with $10 \mathrm{~mL}$ complete media. After incubation, the cells are treated with curcumin $(2.5$ to $20 \mu \mathrm{M})$ alone, radiation 
( 2 to $20 \mathrm{~Gy}$ ) alone or a combination of curcumin $(2$ to $10 \mu \mathrm{M})$ and radiation $(2 \mathrm{~Gy})$. After 12 days of incubation period, the colonies were stained with $10 \mathrm{~mL}$ of Crystal Violet $(0.625 \%$ in methanol). Colonies of more than 50 cells were counted. Plating efficiency was used to calculate percent survival for all experimental groups. Plating efficiency was calculated from the number of colonies formed divided by the number of cells seeded. The percent survival of the control group was considered $100 \%$. The percent survival of the experimental groups was calculated as 100/plating efficiency of control x plating efficiency of the experimental group.

\section{Combination index}

The combination index $(\mathrm{CI})$ was calculated according to the method of Chou and Talalay (1984). The CI value for different combination groups of curcumin and radiation was calculated using the equation $\mathrm{CI}=\mathrm{D} 1 / \mathrm{Dx} 1+\mathrm{D} 2 / \mathrm{Dx} 2$, where $\mathrm{D} 1$ and $\mathrm{D} 2$ are the concentrations of curcumin and radiation respectively used in the combination to achieve a specific $(x \%)$ effect. Dx1 and Dx2 are the concentrations of curcumin and radiation respectively required to achieve the same effect as single agents. Dx1 and Dx2 are calculated from the individual dose response curve for curcumin $(2.5$ to $20 \mu \mathrm{M})$ and radiation ( 2 to $20 \mathrm{~Gy}$ ). A CI value of less than, equal to, and more than 1 indicates synergy, additivity, and antagonism respectively.

\section{Statistical analysis}

The number of colonies from three replicate clonogenic assay in each experimental group was analyzed using the student's paired t-test $(\mathrm{p}<0.05)$. The $\mathrm{t}$-test was performed between the following experimental groups: control vs. radiation, control vs. curcumin, curcumin vs. curcumin+radiation, and radiation vs. radiation + curcumin.

\section{Results}

The study was undertaken to examine the effect of curcumin and radiation on cell viability, apoptosis and clonogenic cell death in LNCaP (wild-type p53) and PC3 (mutant p53) prostate cancer cells.

The expression of p53 and p53 target genes (p21, gadd45, and bax) was examined in LNCaP cells using RNase protection assay (Figure 2A and 2B) and Western blot analysis (Figure 2C and 2D). The level of phospho-p53 (p-p53 at serine 15) increased $\sim 4$ fold after radiation exposure (Figure $2 \mathrm{C}$ and 2D), but not after curcumin treatment (Figure 2C and 2D) when compared with control. Similarly, the level of $\mathrm{p} 53$ protein expression increased $\sim 1.8$ fold after radiation exposure (Figure 2C, at $6 \mathrm{hr}$ ) and not after curcumin treatment (Figure $2 \mathrm{C})$, indicating that p53 is activated by radiation exposure.

The expression of p21 increased at the RNA level (Figure 2A and 2B) after radiation exposure ( $~ 3$ fold at $6 \mathrm{hr}$ and $24 \mathrm{hr})$, after curcumin treatment $(\sim 1.5$ fold at $6 \mathrm{hr}$ and 3.1 fold at $24 \mathrm{hr})$, and in the presence of both curcumin and radiation ( $\sim 3.6$ fold at $6 \mathrm{hr}$ and 3 fold at $24 \mathrm{hr}$ ) when compared with control. The p21 expression at the protein level (Figure 2C and 2D) increased after radiation exposure $(\sim 5$ fold at 6 hr and 1.5 fold at $24 \mathrm{hr})$, and in the presence of both curcumin and radiation ( $\sim 6$ fold at $6 \mathrm{hr}$ and 1.7 fold at $24 \mathrm{hr}$ ) when compared with

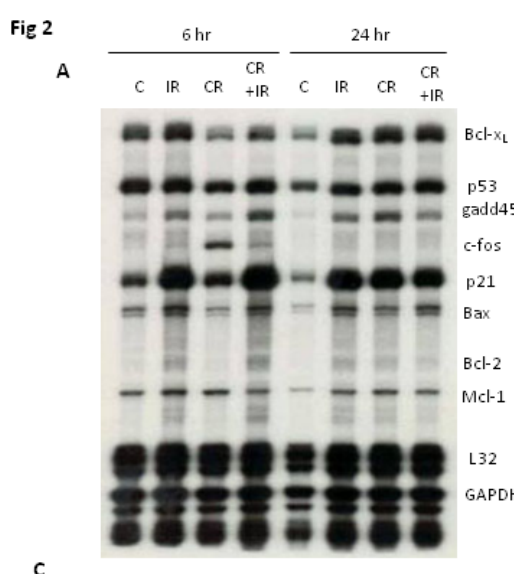

c

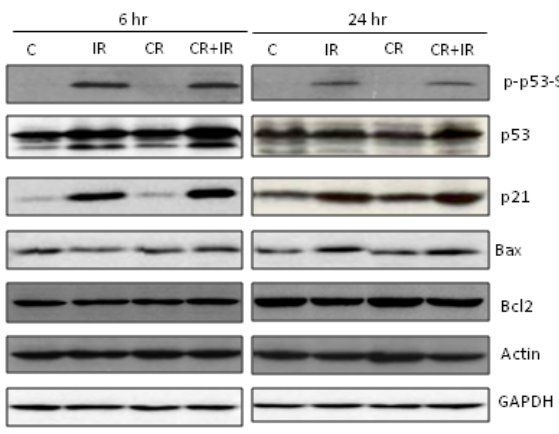

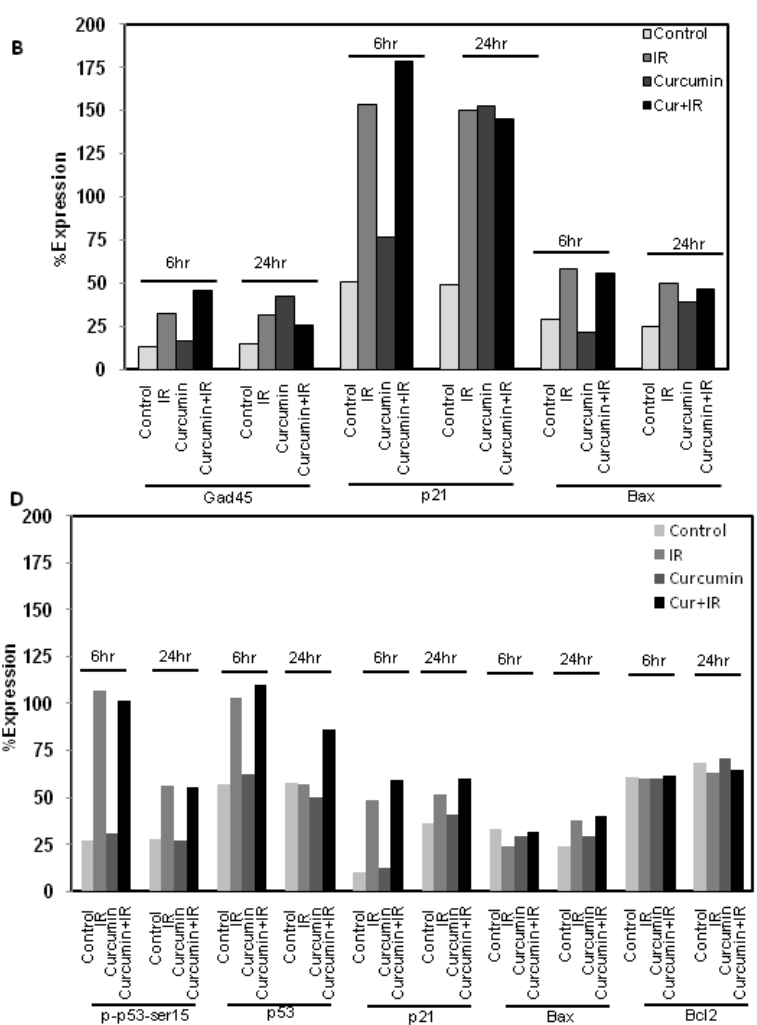

Figure 2: Expression of $p 53$ and $p 53$ target genes by curcumin and radiation in LNCaP cells. A: RNase protection assay (RPA) showing expression of $p 21$, gadd45, and bax at 6 and $24 \mathrm{hr}$ post radiation exposure. L32 and GAPDH are loading controls. C-control, IR- 2 Gy radiation, CR-10 $\mu \mathrm{M}$ curcumin, CR+IR-10 $\mu \mathrm{M}$ curcumin+2 Gy. B: Quantitation of RPA showing gadd45, p21, and bax expression level normalized to GAPDH C: Western blot analysis showing expression of p-p53-Ser 15, p53, p21, bax, bcl2 at 6 and $24 \mathrm{hr}$ post radiation exposure. Actin and GAPDH are loading controls. C-control, IR- $2 \mathrm{~Gy}$ radiation, CR-10 $\mu \mathrm{M}$ curcumin, $\mathrm{CR}+\mathrm{IR}-10 \mu \mathrm{M}$ curcumin +2 Gy. D: Quantitation of Western blot showing p53, p21, bax, and bcl2 expression level normalized to GAPDH. 
Citation: Nayak BK, Krishnegowda NK, Galindo CA, Meltz ML, Swanson GP (2010) Synergistic Effect Between Curcumin (diferuloylmethane) and Radiation on Clonogenic Cell Death Independent of p53 in Prostate Cancer Cells. J Cancer Sci Ther 2: 171-181. doi:10.4172/19485956.1000046

control. The gadd45 expression increased after radiation exposure $(\sim 2.5$ fold at $6 \mathrm{hr}$ and 2.3 fold at $24 \mathrm{hr})$, after curcumin treatment $(\sim 1.3$ fold at $6 \mathrm{hr}$ and 3.2 fold at $24 \mathrm{hr})$, and in the presence of both curcumin and radiation $(\sim 3.5$ fold at $6 \mathrm{hr}$ and 1.9 fold at $24 \mathrm{hr})$ when compared with the control. Bax expression increased at RNA level (Figure 2A) after radiation exposure ( $\sim 2$ fold at $6 \mathrm{hr}$ and 2.1 fold at 24 $\mathrm{hr})$, after curcumin treatment $(\sim 1.6$ fold at $24 \mathrm{hr})$ and in the presence of both curcumin and radiation ( $\sim 2$ fold at $6 \mathrm{hr}$ and 2 fold at $24 \mathrm{hr}$ ) when compared with control. At the protein level (Figure 2C, and $2 \mathrm{D})$, Bax expression increased after radiation exposure ( $\sim 1.6$ fold at $24 \mathrm{hr})$, and in the presence of both curcumin and radiation ( $\sim 1.7$ fold at $24 \mathrm{hr}$ ). There was no change in bcl2 expression after radiation or curcumin treatment (Figure 2C and 2D).

In PC3 cells (Figure 3): the p-p53-Ser15 was not detected and there was no change in expression in mutant p53 protein after radiation or curcumin treatment (Figure $3 \mathrm{C}$ ), indicating that the mutant p53 was not activated by either treatment. The expression of p21 did not change after radiation exposure, but increased after curcumin treatment, and increased in the presence of both curcumin and radiation (Figure $3 \mathrm{~A}$ and $3 \mathrm{~B}$; Figure $3 \mathrm{C}$ and $3 \mathrm{D}$ ) when compared with the control. The expression of p21 increased at the RNA level (Figure 3A and 3B) after curcumin treatment $(\sim 2.5$ fold at $6 \mathrm{hr}$ and 1.3 fold at $24 \mathrm{hr}$ ), and in the presence of both curcumin and radiation $(\sim 2.5$ fold at $6 \mathrm{hr}$ and 4 fold at $24 \mathrm{hr}$ ). The p21 expression at the protein level (Figure 3C and 3D) increased after curcumin treatment $(\sim 1.5$ fold at $6 \mathrm{hr}$ and 2.1 fold at $24 \mathrm{hr})$, and in the presence of both curcumin and radiation $(\sim 1.2$ fold at $6 \mathrm{hr}$ and 2.3 fold at 24 hr). The gadd 45 expression did not change after radiation exposure (Figure 3A), increased after curcumin treatment ( $\sim 2$ fold at $6 \mathrm{hr}$ ), and increased in the presence of both curcumin and radiation $(\sim 2.5$ fold at $6 \mathrm{hr}$ and 2.8 fold at $24 \mathrm{hr}$ ). The bax expression (Figure 3A and 3C) did not change after radiation or curcumin exposure, but increased in the presence of both curcumin and radiation $(\sim 1.5$ fold at 24 $\mathrm{hr}$, Figure 3C) as compared with the control. There was no change in bcl2 expression after radiation or curcumin treatment when compared with the control (Figure 3C and 3D). The results showed that curcumin increased the expression of p 21 and gadd 45 in both the cell lines independent of p53.

The effect of curcumin and radiation on cell cycle arrest was examined by flow cytometry. The cells were treated with curcumin $(10 \mu \mathrm{M})$ alone, radiation $(2 \mathrm{~Gy})$ alone or in combination of curcumin $(10 \mu \mathrm{M})$ with radiation $(2 \mathrm{~Gy})$. For combination treatment, cells were treated with curcumin for $2 \mathrm{hr}$ prior to radiation exposure. The cell cycle distribution was examined after $48 \mathrm{hr}$ post radiation exposure (Figure 4).

The percentage of cells in each phase of the cell cycle for both the LNCaP and PC3 cells is shown in Table 1 and Figure 4. As can be seen,

\begin{tabular}{|c|c|c|c|c|c|c|}
\hline & \multicolumn{3}{|c|}{ LNCaP } & \multicolumn{3}{c|}{ PC3 } \\
\hline Experimental Groups & G1 & S & G2/M & G1 & S & G2/M \\
\hline Control & $55 \%$ & $32 \%$ & $13 \%$ & $33 \%$ & $32 \%$ & $35 \%$ \\
\hline Curcumin 10 $\mu \mathrm{M}$ & $48 \%$ & $26 \%$ & $26 \%$ & $31 \%$ & $26 \%$ & $43 \%$ \\
\hline IR 2 Gy & $60 \%$ & $16 \%$ & $26 \%$ & $25 \%$ & $23 \%$ & $52 \%$ \\
\hline Curcumin 10 $\mu \mathrm{M}+$ IR 2 Gy & $50 \%$ & $17 \%$ & $33 \%$ & $25 \%$ & $25 \%$ & $50 \%$ \\
\hline
\end{tabular}

Table 1: Cell cycle analysis in LNCaP and PC3 cells.
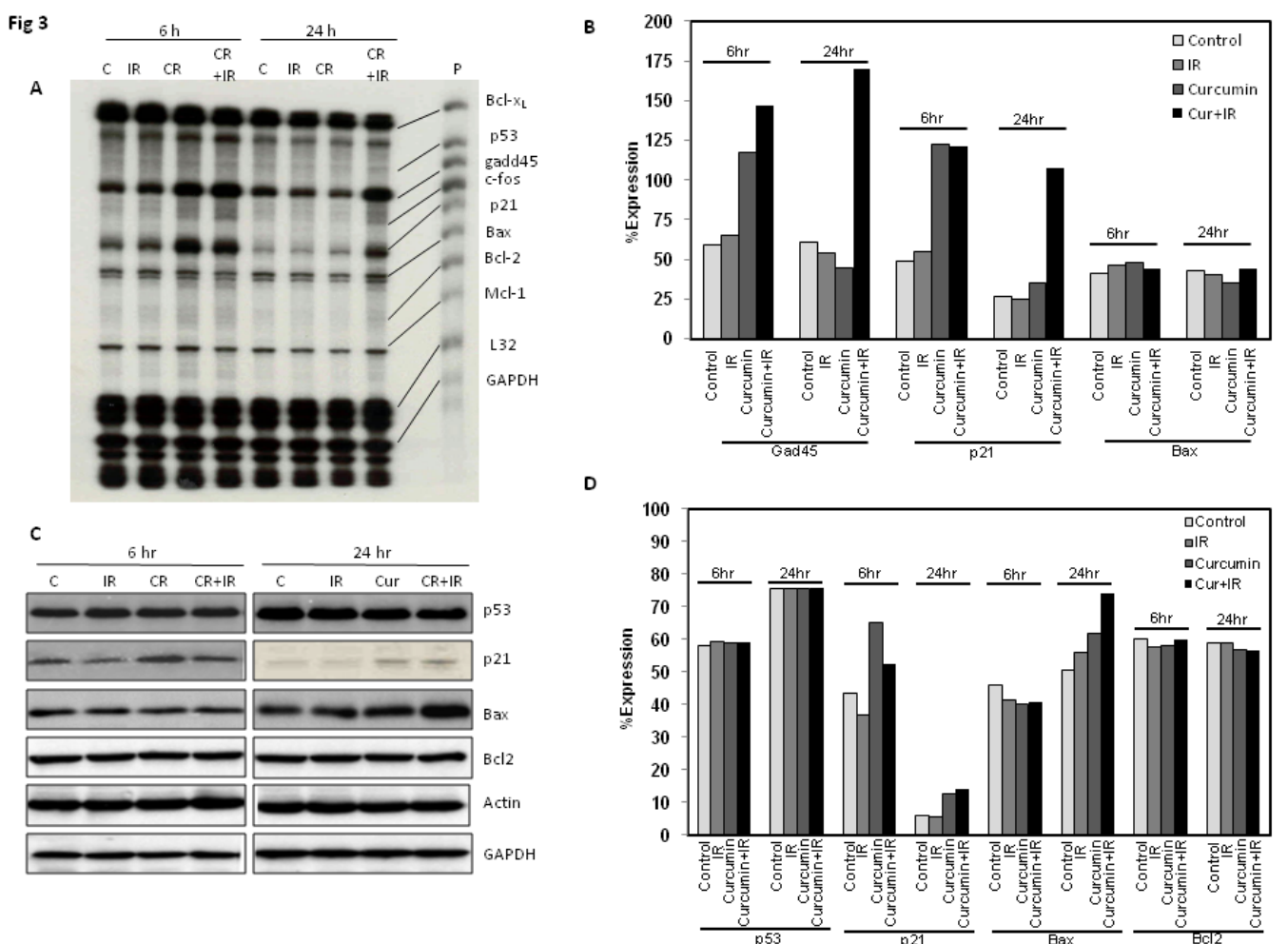

Figure 3: Expression of $p 53$ and $p 53$ target genes by curcumin and radiation in PC3 cells. A: RNase protection assay showing expression of $p 21$, gadd45, and bax at 6 and $24 \mathrm{hr}$ post radiation exposure. L32 and GAPDH are loading controls. P-probe, C-control, IR- 2 Gy radiation, CR-10 $\mu \mathrm{M}$ curcumin, CR+IR-10 $\mu \mathrm{M}$ curcumin+2 Gy. B: Quantitation of RPA showing gadd45, p21, and bax expression level normalized to GAPDH. C: Western blot analysis showing expression of p53, p21, bax, bcl2 at 6 and $24 \mathrm{hr}$ post radiation exposure. Actin and GAPDH are loading controls. C-control, IR- 2 Gy radiation, CR-10 $\mu \mathrm{M}$ curcumin, CR+IR-10 $\mu \mathrm{M}$ curcumin+2 Gy. D: Quantitation of Western blot showing p53, p21, bax, and bcl2 expression level normalized to GAPDH. 
A

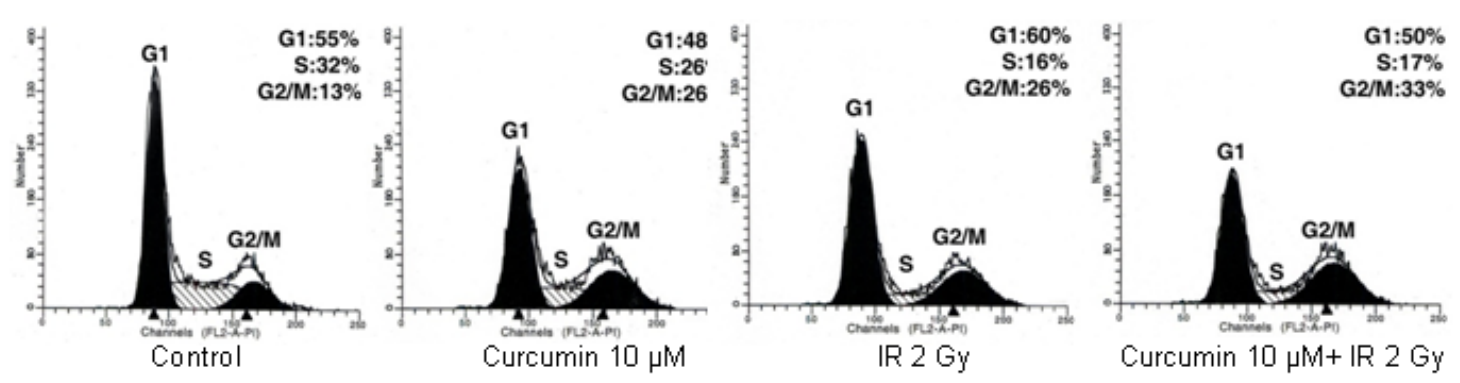

B

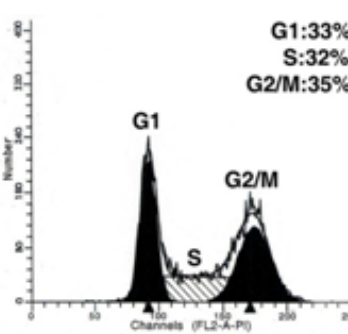

Control

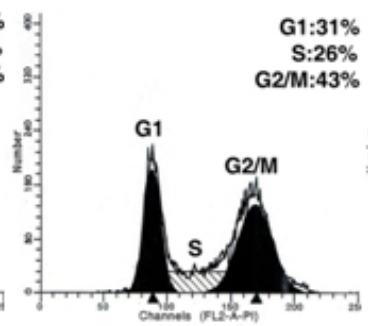

Curcumin $10 \mu \mathrm{M}$

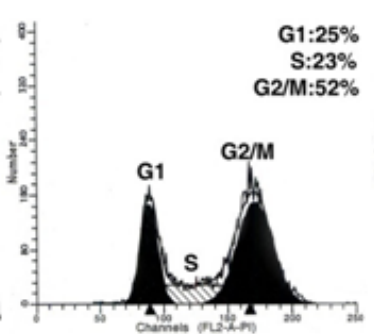

IR 2 Gy

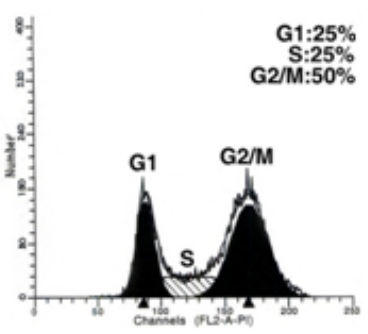

Curcumin $10 \mu \mathrm{M}+\mathrm{IR} 2 \mathrm{~Gy}$

Figure 4: Cell cycle distribution after curcumin and radiation treatment in LNCaP and PC3 cells. Cells were treated with curcumin (10 uM) alone or radiation ( 2 Gy) alone or in combination of curcumin (10 uM) with radiation ( $2 \mathrm{~Gy})$. Cell cycle distribution was examined after $48 \mathrm{hr}$ of radiation exposure and presented as percent $\mathrm{G} 1$, S, and G2/M. A: LNCaP B: PC3.

there was cell cycle arrest in response to curcumin and radiation exposure in both the cell lines with an increase in cells at G2/M.

The effect of curcumin and ionizing radiation (IR) on apoptosis induction was examined either by measuring the level of active caspase 9 or by assessing the level of annexin $\mathrm{V}$ binding. The cells were exposed with radiation (2 Gy) alone or treated with curcumin $(10$ to $50 \mu \mathrm{M})$ alone, or in combination of curcumin $(10$ to $50 \mu \mathrm{M})$ with radiation $(2 \mathrm{~Gy})$. For combination treatment, cells were treated with curcumin for $2 \mathrm{hr}$ prior to radiation exposure. The apoptosis was measured after $48 \mathrm{hr}$ post radiation exposure. The change in apoptosis is shown in Table 2a and Figure 5. As can be seen, at lower

\begin{tabular}{|c|c|c|c|c|}
\hline & \multicolumn{2}{|c|}{ LNCaP } & \multicolumn{2}{c|}{ PC3 } \\
\hline Experimental Groups & $\%$ Apoptosis & $\begin{array}{c}\% \text { survival } \\
\text { (MTT) } \\
\text { Mean } \pm \text { SE }\end{array}$ & $\%$ Apoptosis & $\begin{array}{c}\% \text { survival } \\
\text { (MTT) } \\
\text { Mean } \pm \text { SE }\end{array}$ \\
\hline Control & 8 & 100 & 7 & 100 \\
\hline Curcumin $2.5 \mu \mathrm{M}$ & & $76 \pm 1.8$ & & $76 \pm 1.5$ \\
\hline Curcumin $5 \mu \mathrm{M}$ & & $62 \pm 0.9$ & & $62 \pm 2$ \\
\hline Curcumin 10 $1 \mathrm{M}$ & 11 & $49 \pm 1.8$ & 8 & $50 \pm 1.2$ \\
\hline Curcumin $20 \mu \mathrm{M}$ & 15 & & 12 & \\
\hline Curcumin $50 \mu \mathrm{M}$ & 76 & & 87 & \\
\hline IR 2 Gy & 15 & $78 \pm 1.2$ & 11 & $80 \pm 0.9$ \\
\hline Curcumin 2.5 $\mu \mathrm{M}+$ IR 2 Gy & & $56 \pm 1.2$ & & $63 \pm 1.5$ \\
\hline Curcumin $5 \mu \mathrm{M}+$ IR 2 Gy & & $41 \pm 1.8$ & & $51 \pm 1.5$ \\
\hline Curcumin 10 $\mu \mathrm{M}+$ IR 2 Gy & 17 & $20 \pm 1.8$ & 12 & $42 \pm 0.9$ \\
\hline Curcumin $20 \mu \mathrm{M}+$ IR 2 Gy & 20 & & 15 & \\
\hline Curcumin $50 \mu \mathrm{M}+$ IR 2 Gy & 79 & & 86 & \\
\hline
\end{tabular}

Table 2a: Apoptosis and cell viability (MTT assay) in LNCaP and PC3 cells. Apoptosis data is from a representative experiment and MTT data is from triplicate experiment.

\begin{tabular}{|c|c|c|c|c|}
\hline & \multicolumn{2}{|c|}{ LNCaP } & \multicolumn{2}{c|}{ PC3 } \\
\hline Experimental Groups & \% Apoptosis & $\begin{array}{c}\text { \% survival } \\
(\text { MTT) }\end{array}$ & \% Apoptosis & $\begin{array}{c}\text { \% survival } \\
\text { (MTT) }\end{array}$ \\
\hline Control & 8 & 100 & 7 & 100 \\
\hline Curcumin 2.5 $\mu \mathrm{M}$ & & 76 & & 76 \\
\hline Curcumin 5 $\mu \mathrm{M}$ & & 62 & & 62 \\
\hline Curcumin 10 $\mu \mathrm{M}$ & 11 & 49 & 8 & 50 \\
\hline Curcumin 20 $\mu \mathrm{M}$ & 15 & & 12 & \\
\hline Curcumin 50 $\mu \mathrm{M}$ & 76 & & 87 & \\
\hline IR 2 Gy & 15 & 78 & 11 & 80 \\
\hline Curcumin 2.5 $\mu \mathrm{M}+$ IR 2 Gy & & 56 & & 63 \\
\hline Curcumin 5 $\mu \mathrm{M}+$ IR 2 Gy & & 41 & & 51 \\
\hline Curcumin 10 $\mu \mathrm{M}+$ IR 2 Gy & 17 & 20 & 12 & 42 \\
\hline Curcumin 20 $\mu \mathrm{M}+$ IR 2 Gy & 20 & & 15 & \\
\hline Curcumin 50 $\mu \mathrm{M}+$ IR 2 Gy & 79 & & 86 & \\
\hline
\end{tabular}

Table 2b: Apoptosis and cell viability (MTT assay).

levels, both curcumin and radiation induced apoptosis in both the cell lines, which was only modestly additive with both modalities.

The effect of curcumin and radiation on cell viability was examined using the MTT assay. The cells were exposed with radiation $(2 \mathrm{~Gy})$ alone or treated with curcumin $(2.5$ to $10 \mu \mathrm{M})$ alone, or in combination of curcumin $(2.5$ to $10 \mu \mathrm{M})$ with radiation (2 Gy). The MTT assay was performed after 7 days of radiation exposure. The results are shown in Table $2 \mathrm{~b}$ and Figure 6.

The results showed that the cell viability decreased in presence of both curcumin and radiation as compared to control and radiation exposed cells. There was clearly an additive effect, especially as the curcumin dose increased.

We examined the effect of both curcumin and radiation on 
A
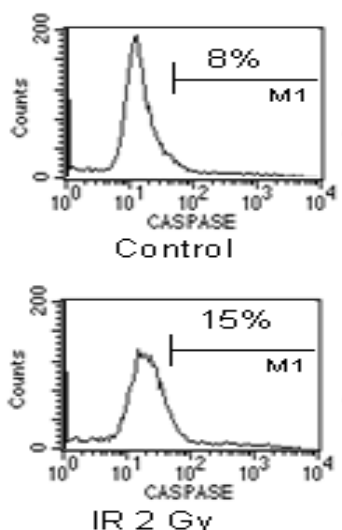

B
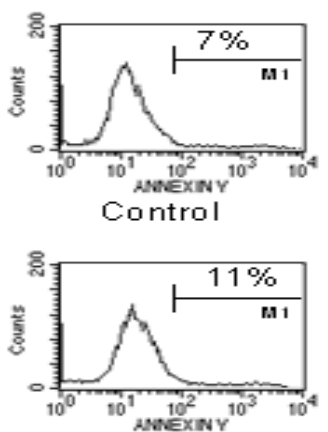

IR $2 \mathrm{~Gy}$
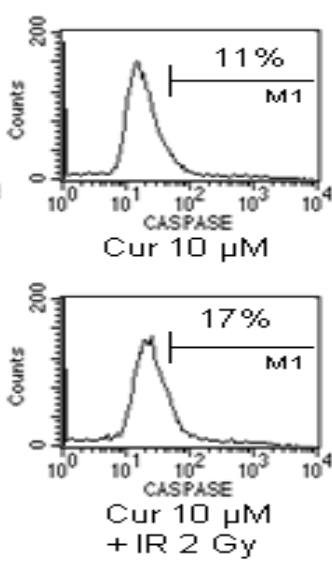

Cur $10 \mathrm{HM}$
$+\mathrm{IR} 2 \mathrm{~Gy}$

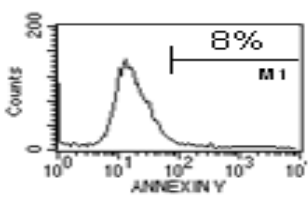

Cur 10 uM

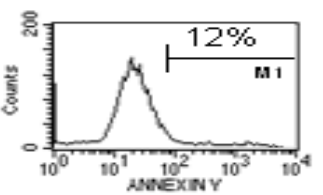

Cur $10 \mu \mathrm{M}$

+ IR $2 \mathrm{~Gy}$
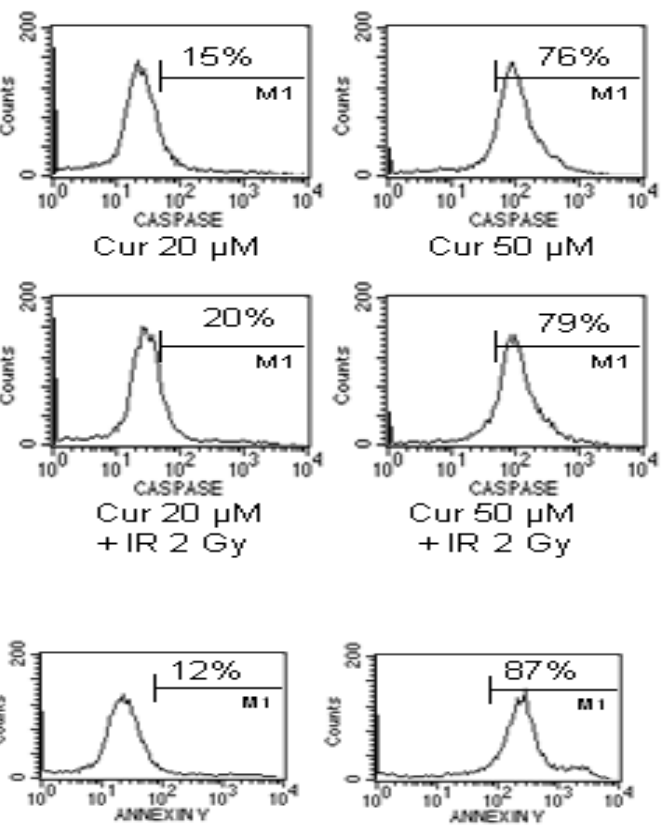

Cur 20 मM

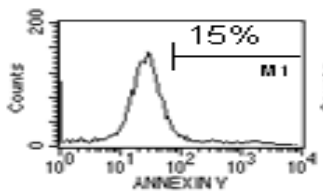

Cur $20 \mu \mathrm{M}$

$+\mathrm{IR} 2 \mathrm{~Gy}$
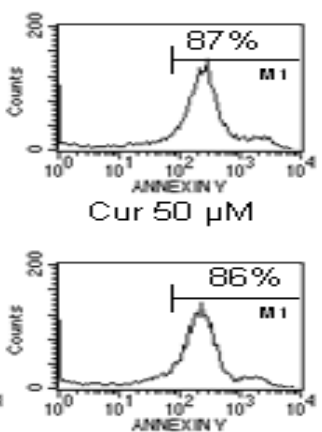

Cur 50 मM

+ IR $2 \mathrm{~Gy}$

Figure 5: Curcumin induces apoptosis in LNCaP and PC3 cells. Cells were treated with curcumin (10, 20, and $50 \mu \mathrm{M})$ alone, radiation (2 Gy) alone or in combination of curcumin with radiation. A: Caspase 9 assay in $\mathrm{LNCaP}$ cells B: Annexin V binding assay in PC3 cells.

A

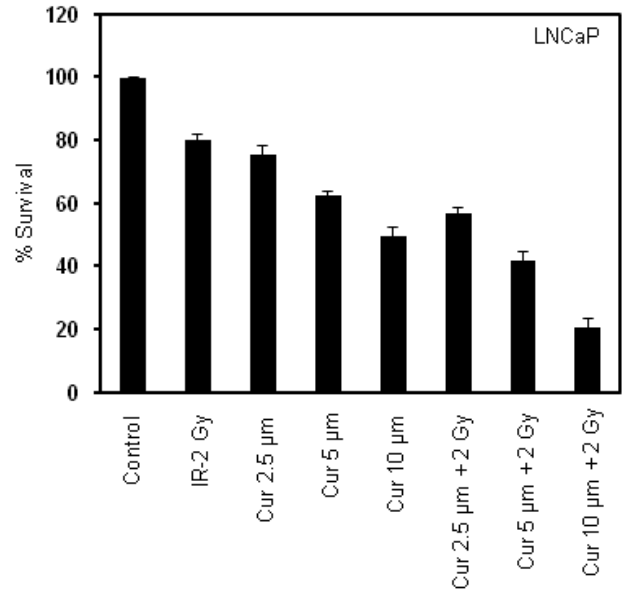

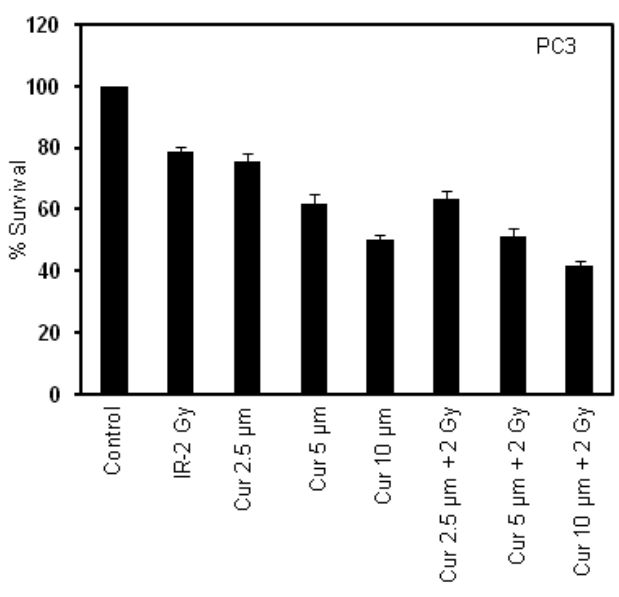

Figure 6: Decrease in cell viability in LNCaP and PC3 cells examined using MTT assay. Cells were treated with curcumin (2.5, 5 , and $10 \mu \mathrm{M})$ alone, radiation ( 2 Gy) alone or in combination of curcumin with radiation. A: LNCaP B: PC3 cells.

clonogenic cell death by performing colony forming assay. Two independent colony forming experiment were performed in both the cell lines; triplicate plates were included in each experiment. A doseresponse curve for curcumin alone, radiation alone and combination of curcumin and radiation is presented in Figure 7. Combination index
(CI) value for combination of curcumin and radiation is shown in Table 3a. A representative set of data and figures from one experiment are presented in Figures 8 and 9. Clonogenic cell death is a predominant mechanism of cell death caused by radiation that includes late apoptotic and reproductive (senescence) cell death (Dewey et al., 
A
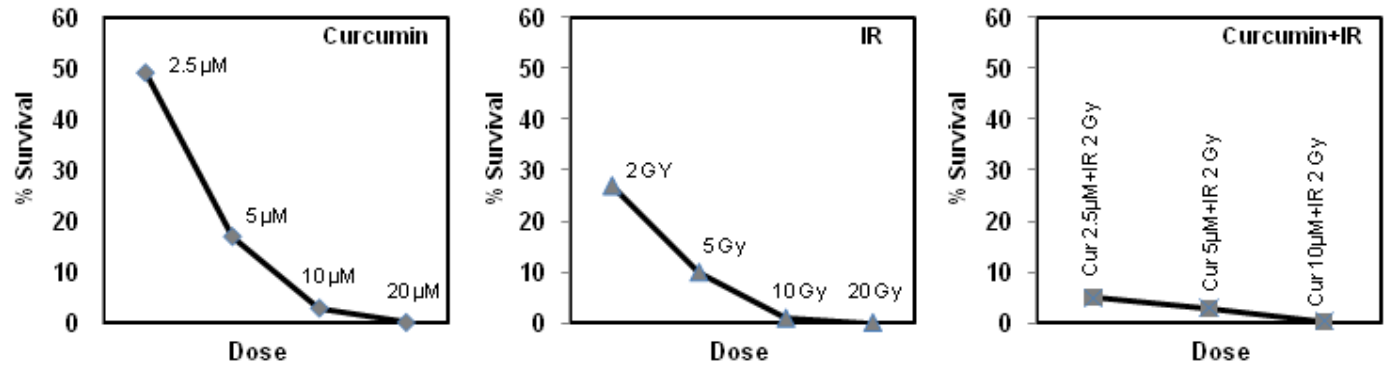

B
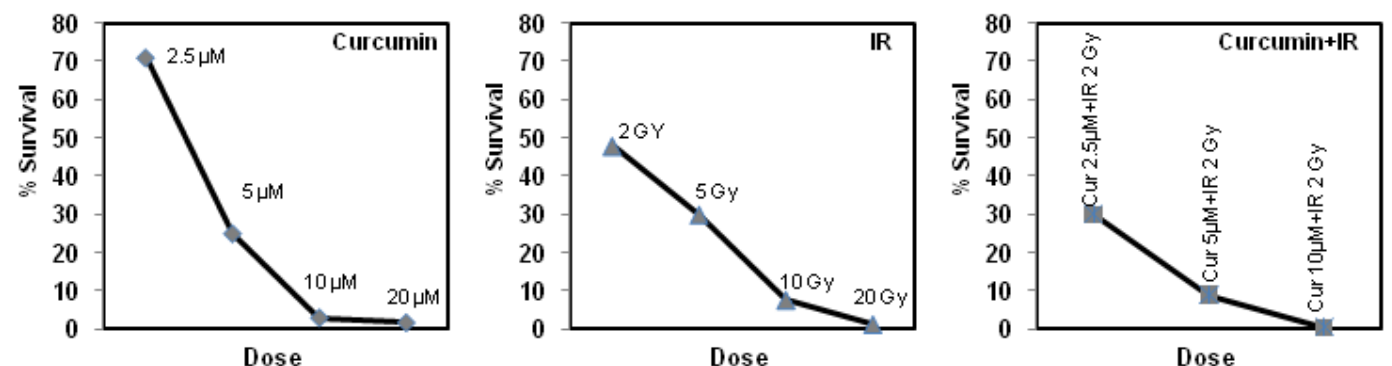

Figure 7: Dose-response curve for curcumin, radiation, and curcumin+radiation on colony formation. A: LNCaP B: PC3.

\begin{tabular}{|c|c|c|c|c|c|c|c|c|}
\hline & \multicolumn{4}{|l|}{ LNCaP } & \multicolumn{4}{|l|}{ PC3 } \\
\hline Experimental Groups & $\begin{array}{l}\text { Average colonies } \\
\text { from three plates } \\
\text { Mean } \pm S E\end{array}$ & $\begin{array}{l}\text { Plating } \\
\text { efficiency (\%) }\end{array}$ & $\begin{array}{l}\text { Percent } \\
\text { survival }\end{array}$ & $\mathrm{Cl}$ & $\begin{array}{l}\text { Average colonies from three } \\
\text { plates Mean } \pm \text { SE }\end{array}$ & $\begin{array}{l}\text { Plating efficiency } \\
(\%)\end{array}$ & $\begin{array}{l}\text { Percent } \\
\text { survival }\end{array}$ & $\mathrm{Cl}$ \\
\hline Control & $2142 \pm 11.1$ & 23.8 & 100 & & $421 \pm 10.1$ & 21 & 100 & \\
\hline IR 2 Gy & $583 \pm 12$ & 6.4 & 27 & & $198 \pm 6.2$ & 10 & 48 & \\
\hline IR 5 Gy & $215 \pm 5.2$ & 2.4 & 10 & & $127 \pm 5.0$ & 6.4 & 30 & \\
\hline IR $10 \mathrm{~Gy}$ & $22 \pm 1.2$ & 0.2 & 1 & & $32 \pm 3.2$ & 1.6 & 7.6 & \\
\hline IR 20 Gy & $3 \pm 0.4$ & 0.03 & 0.1 & & $5 \pm 1.1$ & 0.25 & 1.2 & \\
\hline Curcumin $2.5 \mu \mathrm{M}$ & $1066 \pm 8.2$ & 11.8 & 49 & & $305 \pm 10.3$ & 15 & 71 & \\
\hline Curcumin $5 \mu \mathrm{M}$ & $354 \pm 7.5$ & 4 & 17 & & $105 \pm 3.5$ & 5 & 25 & \\
\hline Curcumin $10 \mu \mathrm{M}$ & $60 \pm 5.5$ & 0.7 & 3 & & $14 \pm 3.5$ & 0.7 & 3 & \\
\hline Curcumin $20 \mu \mathrm{M}$ & $5 \pm 3.0$ & 0.05 & 0.2 & & $7 \pm 1.3$ & 0.35 & 1.7 & \\
\hline Curcumin $2.5 \mu \mathrm{M}+\mathrm{IR} 2 \mathrm{~Gy}$ & $110 \pm 4.6$ & 1.2 & 5 & 0.78 & $128 \pm 12.0$ & 6 & 30 & 0.92 \\
\hline Curcumin $5 \mu \mathrm{M}+\mathrm{IR} 2 \mathrm{~Gy}$ & $74 \pm 3.5$ & 0.8 & 3 & 0.47 & $37 \pm 6.0$ & 2 & 9 & 0.50 \\
\hline Curcumin $10 \mu \mathrm{M}+\mathrm{IR} 2 \mathrm{~Gy}$ & $09 \pm 1.2$ & 0.1 & 0.4 & 0.26 & $2 \pm 0.6$ & 0.1 & 0.5 & 0.16 \\
\hline
\end{tabular}

Table 3a: Clonogenic cell survival in LNCaP and PC3 cells. Cl-combination index.

\begin{tabular}{|c|c|c|c|c|c|c|}
\hline & \multicolumn{3}{|l|}{ LNCaP } & \multicolumn{3}{|l|}{ PC3 } \\
\hline Experimental Groups & $\begin{array}{l}\text { Average colonies } \\
\text { from three plates }\end{array}$ & $\begin{array}{l}\text { Plating efficiency } \\
(\%)\end{array}$ & Percent survival & $\begin{array}{l}\text { Average colonies } \\
\text { from three plates }\end{array}$ & $\begin{array}{l}\text { Plating efficiency } \\
(\%)\end{array}$ & Percent survival \\
\hline Control & 2142 & 23.8 & 100 & 421 & 21 & 100 \\
\hline IR 2 Gy & 583 & 6.4 & 27 & 198 & 10 & 48 \\
\hline Curcumin $2.5 \mu \mathrm{M}$ & 1066 & 11.8 & 49 & 305 & 15 & 71 \\
\hline Curcumin $5 \mu \mathrm{M}$ & 354 & 4 & 17 & 105 & 5 & 25 \\
\hline Curcumin $10 \mu \mathrm{M}$ & 60 & 0.7 & 3 & 14 & 0.7 & 3 \\
\hline Curcumin $2.5 \mu \mathrm{M}+\mathrm{IR} 2 \mathrm{~Gy}$ & 110 & 1.2 & 5 & 128 & 6 & 30 \\
\hline Curcumin $5 \mu \mathrm{M}+\mathrm{IR} 2 \mathrm{~Gy}$ & 74 & 0.8 & 3 & 37 & 2 & 9 \\
\hline Curcumin $10 \mu \mathrm{M}+\mathrm{IR} 2 \mathrm{~Gy}$ & 09 & 0.1 & 0.4 & 2 & 0.1 & 0.5 \\
\hline
\end{tabular}

Table 3b: Clonogenic Cell survival.

1971; Lehman et al., 2007). The cells were exposed with radiation ( 2 to $20 \mathrm{~Gy}$ ) alone or treated with curcumin $(2.5$ to $20 \mu \mathrm{M})$ alone, or in combination of curcumin $(2.5$ to $10 \mu \mathrm{M})$ with radiation $(2 \mathrm{~Gy})$. The clonogenic assay was performed after 12 days of radiation exposure. Table 3b shows the percent survival and combination index (CI) values. The combination of curcumin with radiation had synergistic effect (CI value less than 1 in all combinations) on clonogenic cell death in both the cell lines regardless of p53.

The effect of combination of curcumin and radiation compared with curcumin or radiation alone was statistically significant in both the cell types. In LNCaP cells, the p values were: IR 2 Gy vs. curcumin $2.5 \mu \mathrm{M}+\mathrm{IR} 2 \mathrm{~Gy}(\mathrm{p}=0.001)$, IR 2 Gy vs. curcumin $5 \mu \mathrm{M}+\mathrm{IR}$ 2 Gy $(\mathrm{p}=0.0009)$, IR 2 Gy vs. curcumin $10 \mu \mathrm{M}+\mathrm{IR} 2 \mathrm{~Gy}(\mathrm{p}=0.0003)$, 
Citation: Nayak BK, Krishnegowda NK, Galindo CA, Meltz ML, Swanson GP (2010) Synergistic Effect Between Curcumin (diferuloylmethane) and Radiation on Clonogenic Cell Death Independent of p53 in Prostate Cancer Cells. J Cancer Sci Ther 2: 171-181. doi:10.4172/19485956.1000046

A

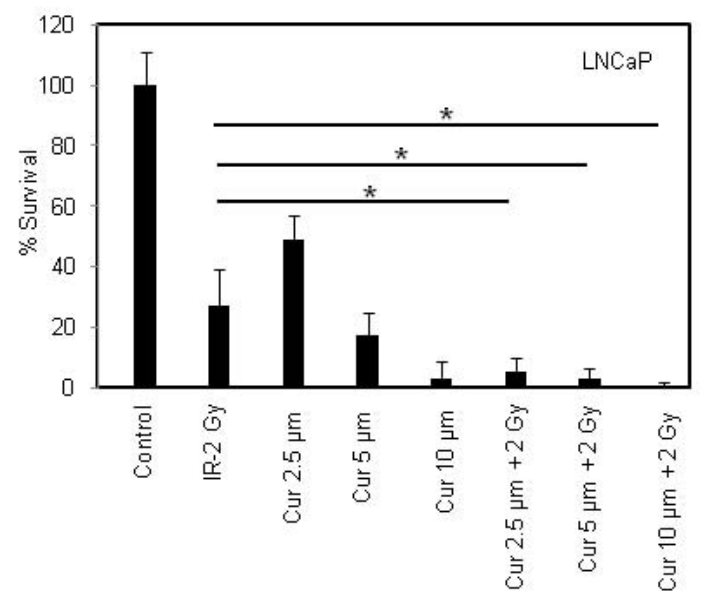

B

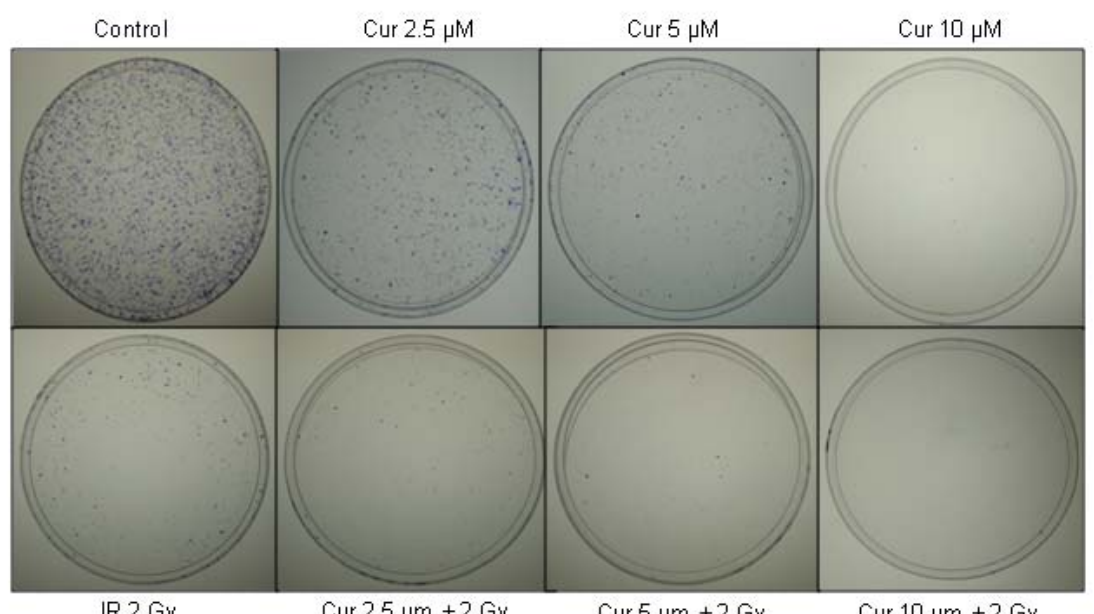

Figure 8: Synergistic effect of curcumin and radiation on clonogenic cell death in LNCaP cells. Cells were treated with curcumin $(2.5,5$, and $10 \mu \mathrm{M})$ alone, radiation ( 2 Gy) alone or in combination of curcumin with radiation. A: Bar chart showing percent survival in different experimental groups ( $\left.{ }^{*} \mathrm{p}<0.05\right)$. B: A representative clonogenic assay showing different experimental groups.

curcumin $2.5 \mu \mathrm{M}$ vs. curcumin $2.5 \mu \mathrm{M}+\mathrm{IR} 2 \mathrm{~Gy}(\mathrm{p}=0.0005)$, curcumin $5 \mu \mathrm{M}$ vs. curcumin $5 \mu \mathrm{M}+\mathrm{IR} 2 \mathrm{~Gy}(\mathrm{p}=0.0008)$, and curcumin $10 \mu \mathrm{M}$ vs. curcumin $10 \mu \mathrm{M}+\mathrm{IR} 2 \mathrm{~Gy}(\mathrm{p}=0.009)$. In PC3 cells, the $\mathrm{p}$ values were: IR 2 Gy vs. curcumin $2.5 \mu \mathrm{M}+\mathrm{IR} 2 \mathrm{~Gy}(\mathrm{p}=0.027)$, IR 2 Gy vs. curcumin $5 \mu \mathrm{M}+\mathrm{IR} 2 \mathrm{~Gy}(\mathrm{p}=0.001)$, IR 2 Gy vs. curcumin $10 \mu \mathrm{M}+\mathrm{IR}$ 2 Gy $(\mathrm{p}=0.001)$, curcumin $2.5 \mu \mathrm{M}$ vs. curcumin $2.5 \mu \mathrm{M}+\mathrm{IR} 2$ Gy $(\mathrm{p}=0.0004)$, curcumin $5 \mu \mathrm{M}$ vs. curcumin $5 \mu \mathrm{M}+\mathrm{IR} 2 \mathrm{~Gy}(\mathrm{p}=0.01)$, and curcumin $10 \mu \mathrm{M}$ vs. curcumin $10 \mu \mathrm{M}+\mathrm{IR} 2 \mathrm{~Gy}(\mathrm{p}=0.05)$.

\section{Discussion}

Radiotherapy is one important treatment choice for prostate cancer (Swanson, 2006; Thompson et al., 2007). A conventional radiation dose of $72 \mathrm{~Gy}$ is preferred as the treatment modality for management of prostate cancers. Radiation dose escalation to improve effectiveness of radiotherapy is achieved mainly through the use of intensity modulated radiation therapy (IMRT) or brachytherapy. However, radioresistance of prostate cancer cells remains a limitation of radiotherapy. Research efforts are needed to identify and develop new agents that can be used as radiosensitizers. Epidemiologic studies indicate that lower incidence of prostate cancer in Asian populations than Western populations may be due to differences in their food habits (Hebert et al., 1998; Denis et al., 1999; Hsing et al., 2000). The dietary spice curcumin is one such phytochemical. Curcumin has been shown to have diverse anti-cancer properties and could be developed as a potent therapeutic agent for prostate cancer treatment (Aggarwal, 2008; Khan et al., 2010). The aim of this study was to examine the effect of curcumin and radiation on cell viability, apoptosis, and clonogenic cell death in prostate cancer cells with wild-type and mutant p53 status. We clearly show that combination treatment of curcumin and radiation had a synergistic effect on clonogenic cell death in prostate cancer cells independent of the p53 status.

The radiosensitivity of prostate cancer cells has been shown to be associated with different molecular pathways, such as, bcl-2 (Chendil et al., 2004; Scott et al., 2002; An et al., 2007), mdm-2 (Mu et al., 2004; Lehman et al., 2007), AP-1 and NF-אB (Mukhopadhyay et al., 2001; Chendil et al., 2004), androgen receptor (Nakamura et al., 2002; Choi et al., 2010) and PI3 kinase/Akt (Li et al., 2007; Yu et al., 2008). Most of these above mentioned pathways have been shown to be modulated by curcumin (Aggarwal, 2008; Khan et al., 2010). Curcumin induces apoptosis by downregulating bcl-2 (Mukhopadhyay et al., 2001; Chendil et al., 2004), cyclin D1 (Mukhopadhyay et al., 2002), AP-1 and NF- $\kappa B$ transcription factors (Mukhopadhya et al., 2001), EGFR signaling pathway (Kim et al., 2006), and by activating p53 


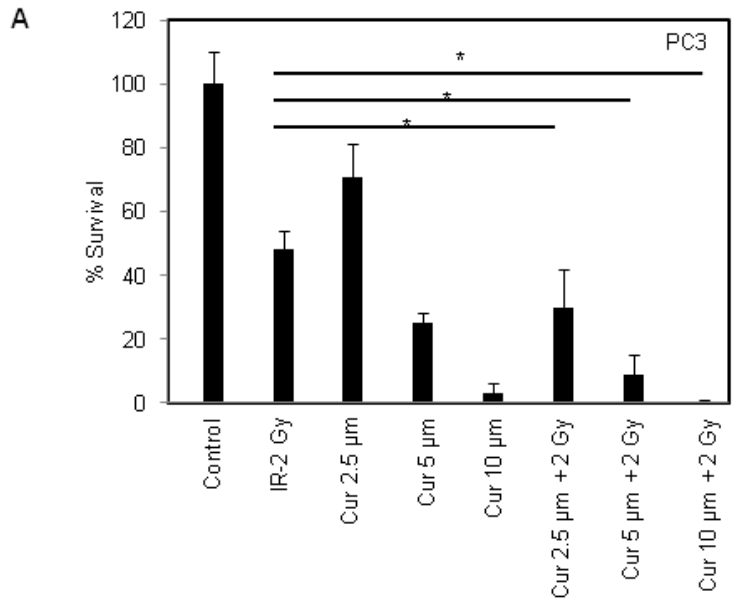

B

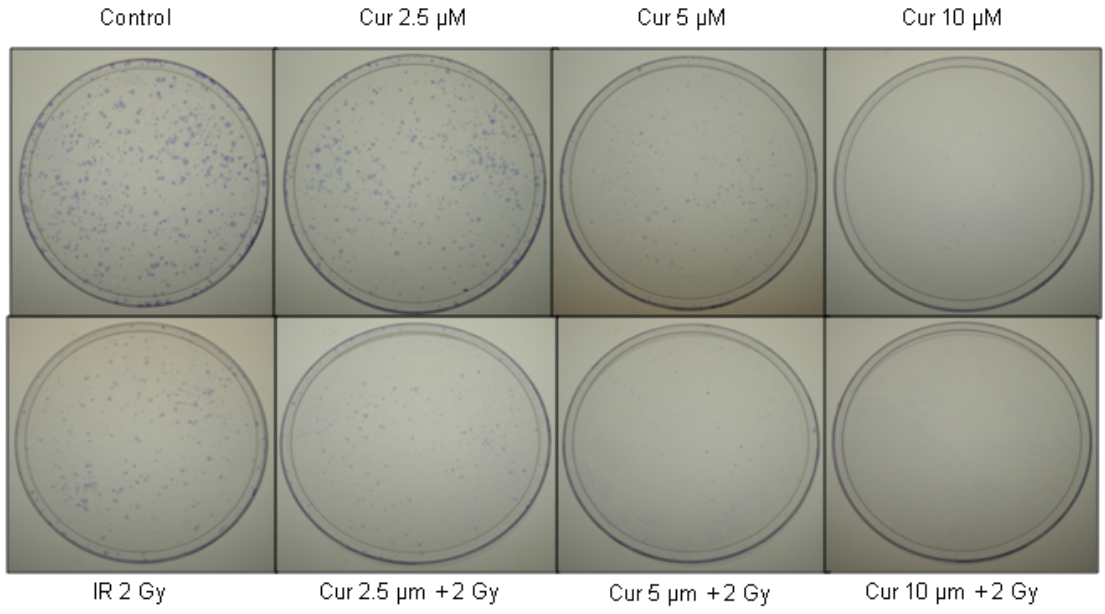

Figure 9: Synergistic effect of curcumin and radiation on clonogenic cell death in PC 3 cells. Cells were treated with curcumin $(2.5,5$, and $10 \mu \mathrm{M})$ alone, radiation $(2$ $\mathrm{Gy})$ alone or in combination of curcumin with radiation. A: Bar chart showing percent survival in different experimental groups ( $\left.{ }^{*} \mathrm{p}<0.05\right)$. B: A representative clonogenic assay showing different experimental groups.

and bax (Shankar and Srivastava, 2007) in different prostate cancer cells. It is reported that curcumin can inhibit cell proliferation and induce apoptosis in androgen-dependent, androgen-independent and metastatic prostate cancer cells (Dorai et al., 2000, Deeb et al., 2003; Dorai et al., 2004). Recently it has been shown that curcumin augmented the inhibitory effect of radiation on growth of head and neck (Khafif et al., 2009; Yallapu et al., 2010) and ovarian cancer (Javvadi et al., 2010). Chendil et al. (2004) have shown that curcumin can enhance radiation-induced apoptosis in prostate cancer cells by altering bcl2: bax ratio. In the present study we show that wild type p53 was activated by radiation and not by curcumin (Figure 2C). However, curcumin induced p21 and gadd 45 expression independent of p53 in PC3 cells (Figure 3) and there was induction of cell growth arrest (Figure 4) and apoptosis (Figure 5) by curcumin in both the LNCaP and PC3 cell lines. The role of p 21 and gadd 45 in cell growth arrest and apoptosis independent of p53 is well documented (Sheikh et al., 2000; Don et al., 2001; Hirose et al., 2003; Zhang et al., 2007). Though curcumin induced apoptosis, combination of curcumin and radiation did not show enhancement of apoptosis examined using caspase 9 and annexin $V$ assays (Figure 5). This could be due to the fact that a 2 Gy dose of radiation resulted only in cell growth arrest and there was no induction of apoptosis observed in our study examined within 48 hours of radiation exposure. However, clonogenic assay (performed after 12 days of exposure) showed a synergistic effect between curcumin and radiation in both the cell lines (Figure 8, 9 and Table 3a). This may be due to the fact that clonogenic cell death takes into account the late apoptotic cell death and the reproductive (senescence) cell death (Dewey et al., 1971; Lehman et al., 2007). Recently, Lehman et al. (2007) have reported that p53 protein is essential for irradiation-induced senescence and clonogenic death of prostate cancer cells. Our results show radiation-induced clonogenic cell death in PC3 cells having mutant p53 (Figure 9 and Table 3b). However, the clonogenic survival in LNCaP cells with normal p53 was lower $(27 \%)$ than the PC3 cells with mutant p53 (48\%). Further, combination of curcumin and radiation had a synergistic effect on clonogenic cell death in $\mathrm{LNCaP}$ and PC3 cells regardless of the p53 status.

To improve therapeutic outcomes, radiotherapy is often combined with chemotherapeutic drugs (Belka et al. 2004; Garzotto et al., 1999; Swanson et al., 2006). Curcumin and curcumin analogues are being developed as potential anti-prostate cancer agents (Lin et al., 2006). It has been shown that curcumin sensitizes colorectal cancer xenografts in nude mice to radiation (Kunnumakkara et al., 2008). Phase I and phase II clinical trials using curcumin alone has 
Citation: Nayak BK, Krishnegowda NK, Galindo CA, Meltz ML, Swanson GP (2010) Synergistic Effect Between Curcumin (diferuloylmethane) and Radiation on Clonogenic Cell Death Independent of p53 in Prostate Cancer Cells. J Cancer Sci Ther 2: 171-181. doi:10.4172/19485956.1000046

been undertaken in colorectal and pancreatic cancers (Sharma et al., 2001; Dhillon et al., 2008). Phase I clinical trial using combination of curcumin and docetaxel has been initiated in patients with advanced and metastatic breast cancer (Bayet-Robert et al., 2010). However, there is no report of any preclinical or clinical trial study using combination of curcumin and radiation in prostate cancer. In this report, we clearly show a synergistic effect between curcumin and radiation on apoptosis induction and clonogenic cell death in prostate cancer cells. These findings highlight the potential of curcumin in radiosensitizing prostate cancer cells and merits future clinical trials using combination of curcumin and radiation in prostate cancers.

\section{Acknowledgments}

This work was supported by institutional grant (UTHSCSA) to GPS and University Research Council (UTHSCSA) grant No. 123953 to BKN. The authors acknowledge the support of the Institutional flow cytometry core facility, which is supported by the NCI CTRC grant P30CA 54174. We appreciate the help of Dr. Senlin Li and Dr. Biju K. Chandu, Department of Medicine, for their assistance in radiation exposure.

\section{References}

1. Aggarwal BB (2008) Prostate cancer and curcumin: Add spice to your life Cancer Biol Ther 7: 1436-1440.

2. Aggarwal BB, Shishodia S, Takada Y, Banerjee S, Newman RA, et al. (2005) Curcumin suppresses the palcitaxel-induced nuclear factor-kB pathway in breast cancer cells and inhibits lung metastasis of human breast cancer in nude mice. Clin Cancer Res 11: 7490-7498.

3. Ammon HP, Wahl MA (1991) Pharmacology of Curcuma longa. Planta Med 57: 1-7.

4. An J, Chervin AS, Nie A, Ducoff HS, Huang Z (2007) Overcoming the radioresistance of prostate cancer cells with a novel $\mathrm{Bcl}-2$ inhibitor. Oncogene 26: 652-661.

5. Anto RJ, Mukhopadhyay A, Denning K, Aggarwal BB (2007) Curcumin (diferuloylmethane) induces apoptosis through activation of caspase-8, BID cleavage and cytochrome $C$ release: its suppression by ectopic expression of $\mathrm{Bcl}-2$ and $\mathrm{Bcl}-\mathrm{xL}$. Carcinogenesis 23:143-150.

6. Bayet-Robert M, Kwiatkowski F, Leheurteur M, Gachon F, Planchat E, et al. (2010) Phase I escalation trial of docetaxel plus curcumin in patients with advanced and metastatic breast cancer. Cancer Biol Ther 9: 8-14.

7. Belka C, Jendrossek V, Pruschy M, Vink S, Verheij M, et al. (2004) Apoptosismodulating agents in combination with radiotherapy - current status and outlook. Int J Radiat Oncol Biol Phys 58: 542-554.

8. Bookstein R, MacGrogan D, Hilsenbeck SG, Sharkey F, Allredb DC (1993) P53 is mutated in a subset of advanced -stage prostate cancers. Cancer Res 53 : 3369-3373.

9. Chendil D, Ranga RS, Meigooni D, Sathishkumar S, Ahmed MM (2004) Curcumin confers radiosensitizing effect in prostate cancer cell line PC3. Oncogene 23: 1599-1607.

10. Cheng AL, Hsu CH, Lin JK, Hsu MM, Ho YF, et al. (2001) Phase I clinical trial of curcumin, a chemopreventive agent, in patients with high-risk or pre-malignant lesions. Anticancer Res 21: 2895-2900.

11. Chi SG, deVere White RW, Meyers FJ, Siders DB, Lee F, et al. (1994) p53 in prostate cancer: frequent expressed transition mutations. J Natl Cancer Inst 86: 926-933.

12. Choi HY, Lim JE, Hong JH (2010) Curcumin interrupts the interaction between the androgen receptor and Wnt/ $\beta$-catenin signaling pathway in LNCaP prostate cancer cells. Prostate Cancer Prostatic Dis (Epub ahead of print).

13. Chou TC, Talalay P (1984) Quantitative analysis of dose-effect relationship: the combined effects of multiple drugs or enzyme inhibitors. Adv Enzyme Regul 22: 27-55.

14. Corson TW, Crews CM (2007) Molecular understanding and modern application of traditional medicines: Triumphs and trials. Cell 130: 769-774.

15. Deeb D, Xu YX, Jiang H, Gao X, Janakiraman N, et al. (2003) Curcumin (Diferuloyl-methane) enhances tumor necrosis factor-related apoptosis- inducing ligand-induced apoptosis in LNCaP prostate cancer cells. Mol Cancer Ther 2: 95-103.

16. Denis L, Morton MS, Griffiths K (1999) Diet and its preventive role in prostatic disease. Eur Urol 35: 377-387.

17. Dewey WC, Miller HH, Leeper DB (1971) Chromosomal aberrations and mortality of $x$-irradiated mammalian cells: emphasis on repair. Proc Natl Acad Sci USA 68: 667-671.

18. Dhillon N, Aggarwal BB, Newman RA, Wolff RA, Kunnumakkara AB, et al (2008) Phase II trial of curcumin in patients with advanced pancreatic cancer Clin Cancer Res 14: 4491-4499.

19. Don MJ, Chang YH, Chen KK, Ho LK, Chau YP (2001) Induction of CDK inhibitors (p21waf1 and p27kip1) and bak in the $\beta$-lapachone apoptosis of human prostate cancer cells. Mol Pharmacol 59: 784-794.

20. Dorai T, Dutcher JP, Dempster DW, Wiernik PH (2004) Therapeutic potential of curcumin in prostate cancer-IV: Interference with the osteomimetic properties of hormone refractory C4-2B prostate cancer cells. Prostate 60: 1-17.

21. Dorai T, Gehani N, Katz A (2000) Therapeutic potential of curcumin in human prostate cancer-I. curcumin induces apoptosis in both androgen-dependent and androgen-independent prostate cancer cells. Prostate Cancer Prostatic Dis 3: 84-93.

22. Downing SR, Russell PJ, Jackson $P$ (2003) Alterations of p53 is common in early stage prostate cancer. Can J Urol 10: 1924-1933.

23. Fridman JS, Lowe SW (2003) Control of apoptosis by p53. Oncogene 22: 9030 9040.

24. Garzotto M, Haimovitz-Friedman A, Liao WC, White-Jones M, Huryk R, et al (1999) Reversal of radiation resistance in $\mathrm{LNCaP}$ cells by targeting apoptosis through ceramide synthase. Cancer Res 59: 5194-5201.

25. Gumerlock PH, Chi SG, Shi XB, Voeller HJ, Jacobson JW, et al. (1997) P53 abnormalities in primary prostate cancer: single starnd conformation polymorphism analysis of complementary DNA in comparison with genomic DNA. The cooperative prostate network. J Natl Cancer Inst 89: 66-71.

26. Haupt S, Berger M, Goldberg Z, Haupt Y (2003) Apoptosis - the p53 network. J Cell Sci 116: 4077-4085.

27. Hebert JR, Hurley TG, Olendzki BC, Teas J, Ma Y, et al. (1998) Nutrutional and socioeconomic factors in relation to prostate cancer mortality: a cross-national study. J Natl Cancer Inst 90: 1637-1647.

28. Herman JG, Stadelman HL, Roselli CE (2009) Curcumin blocks CCL2-induced adhesion, motility and invasion, in part, through down-regulation of CCL2 expression and proteolytic activity. Int J Oncol 34: 1319-1327.

29. Hirose T, Sowa Y, Takahashi S, Saito S, Yasuda C, et al. (2003) p53-independent induction of gadd 45 by histone deacetylase inhibitor: coordinate regulation by transcription factors Oct1 and NF-Y. Oncogene 22: 7762-7773.

30. Hsing AW, Tsao L, Devesa SS (2000) International trends and patterns of prostate cancer incidence and and mortality. Int J Cancer 85: 60-67.

31. Javvadi P, Hertan L, Kosoff R, Datta T, Kolev J, et al. (2010) Thioredoxin Reductase- 1 mediates curcumin-induced radiosensitization of squamous carcinoma cells. Cancer Res 70: 1941-1950.

32. Jemal A, Siegel R, Xu J, Ward E (2010) Cancer statistics 2010. CA Cancer J Clin 60: 277-300.

33. Jutooru I, Chadalapaka G, Lei P, Safe S (2010) Inhibition of NF KB and pancreatic cancer cell and tumor growth by curcumin is dependent on specificity protein down-regulation. J Biol Chem 285: 25332-25344.

34. Kalkner KM, Wahlgren T, Ryberg M, Cohn-Cedermark G, Castellanos E, et al. (2007) Clinical outcome in patients with prostate cancer treated with external beam radiotherapy and high dose-rate iridium 192 brachytherapy boost: A 6-year follow-up. Acta Oncol 46: 909-917.

35. Kawamori T, Lubet R, Steele VE, Kelloff GJ, Kaskey RB, et al. (1999) Chemopreventive effect of curcumin, a naturally occurring anti-inflammatory agent, during the promotion/progression stages of colon cancer. Cancer Res 59: 597-601.

36. Khafif A, Lev-Ari S, Vexler A, Barnea I, Starr A, et al. (2009) Curcumin: A potential radio-enhancer in head and neck cancer. Laryngoscope 119: 20192026.

37. Khan N, Adhami VM, Mukhtar H (2010) Apoptosis by dietary agents for 
prevention and treatment of prostate cancer. Endocr Relat Cancer 17: R39-R52.

38. Khor TO, Keum Y-S, Lin W, Kim J-H, Hu R, et al. (2006) Combined inhibitory effects of curcumin and phenethyl Isothiocyanate on the growth of human PC-3 prostate xenografts in immunodeficient mice. Cancer Res 66: 613-621.

39. Kim J-H, Xu C, Keum Y-S, Reddy B, Conney A, et al. (2006) Inhibition of EGFR signaling in human prostate cancer PC3 cells by combination treatment with b-phenylethyl isothiocyanate and curcumin. Carcinogenesis 27: 475-482.

40. Kunnumakkara AB, Diagaradjane P, Guha S, Deorukhkar A, Shentu S, et al. (2008) Curcumin sensitizes human colorectal cancer xenografts in nude mice to $\mathrm{Y}$-radiation by targeting nuclear factor-kB-regulated gene products. Clin Cancer Res 14: 2128-2136.

41. Lehman BD, McCubrey JA, Jefferson HS, Paine MS, Chappell WH, et al. (2007) A dominant role for p53-dependant cellular senescence in radiosensitization of human prostate cancer cells. Cell Cycle 6: 595-605.

42. Levine AJ, Momand J, Finlay CA (1991) The p53 tumor suppressor gene. Nature 351: 453-456.

43. Li M, Zhang Z, Hill DL, Wang H, Zhang R (2007) Curcumin, a dietary component has anticancer, chemosensitization, and radiosensitization effects by downregulating the MDM2 oncogene through the $\mathrm{PI} / 3 \mathrm{~K} / \mathrm{mTOR} / \mathrm{ETS} 2$ pathway. Cancer Res 67: 1988-1996.

44. Lin L, Shi Q, Nyarko AK, Bestow KF, Wu CC, et al. (2006) Antitumor agents. 250. Design and synthesis of new curcumin analogues as potential anticancer agents. J Med Chem 49: 3963-3972.

45. Mu Z, Hachem P, Agrawal S, Pollack A (2004) Antisense MDM2 sensitizes prostate cancer cells to androgen deprivation, radiation, and the combination. Int J Radiat Oncol Biol Phys 58: 336-343.

46. Mukhopadhyay A, Banerjee S, Stafford LJ, Xia C, Liu M, et al. (2002) Curcumin-induced suppression of cell proliferation correlates with downregulation of cyclin D1 expression and CDK4-mediated retinoblastoma protein phosphorylation. Oncogene 21: 8852-8861.

47. Mukhopadhyay A, Bueso-Ramos C, Chatterjee D, Pantazis P, Aggarwal BB (2001) Curcumin downregulates cell survival mechanisms in human prostate cancer cell lines. Oncogene 20: 7597-7609.

48. Nakamura K. Yasunaga Y, Segawa T, Ko D, Moul JW, et al. (2002) Curcumin down-regulates $A R$ gene expression and activation in prostate cancer cell lines. Int J Oncol 21: 825-830.

49. Nayak BK, Das GM (2002) Stabilization of p53 and transactivation of its target genes in response to replication blockade. Oncogene 21:7226-7229.

50. Razoky C, Grignon DJ, Li Y, Gheiler E, Gururajanna B, et al. (1999) P53 gene alterations in prostate cancer after radiation failure and their association with clinical outcome: a molecular and immunohistochemical analysis. Pathol Res Pract 195: 129-135.

51. Ritter MA, Gilchrist KW, Voytovich M, Chappell RJ, Verhoven BM (2002) The role of p53 in radiation therapy outcomes for favorable-to-intermediate-risk prostate cancer. Int J Radiat Oncol Biol Phys 53: 574-580.

52. Rosen EM, Fan SJ, Rockwell S, Goldberg ID (1999) The molecular and cellular basis of radiosensitivity: Implications for understanding how normal tissues and tumors respond to therapeutic radiation. Cancer Invest 17: 56-72.
53. Scott SL, Higdon R, Beckett L, Shi XB, deVere White RW, et al. (2002) BCL2 antisense reduces prostate cancer cell survival following irradiation. Cancer Biother Radiopharm 17: 647-656.

54. Shankar S, Srivastava RK (2007) Bax and Bak genes are essential for maximum apoptotic response by curcumin, a polyphenolic compound and cancer chemopreventive agent derived from turmeric, Curcuma longa. Carcinogenesis 28: 1277-1286.

55. Shankar S, Srivastava RK (2007) Involvement of Bcl-2 family members, phosphatidylinositol 3' kinase/AKT and mitochondrial p53 in curcumin (diferulolylmethane)-induced apoptosis in prostate cancer. Int J Oncol 30: 905918.

56. Sharma RA, Euden SA, Platton SL, Cooke DN, Shafayat A, et al. (2004) Phase I clinical trial of oral curcumin: biomarkers of systemic activity and compliance. Clin Cancer Res 10: 6847-6854.

57. Sharma RA, McLelland HR, Hill KA, Ireson CR, Euden SA, et al. (2001) Pharmacodynamic and pharmacokinetic study of oral curcuma extract in patients with colorectal cancer. Clin Cancer Res 7: 1894-1900.

58. Sheikh MS, Hollander MC, Fornance AJ Jr. (2000) Role of gadd45 in apoptosis Biochem Pharmacol 59: 43-45.

59. Shishodia S, Chaturvedi MM, Aggarwal BB (2007) Role of curcumin in cancer therapy. Curr Probl Cancer 31: 243-305.

60. Skvortsova I, Skvortsov S, Stasyk T, Raju U, Popper BA, et al. (2008) Intracellular signaling pathways regulating radioresistance of human prostate carcinoma cells. Proteomics 8: 4521-4533.

61. Stapleton AM, Timme TL, Gousse AE, Li QF, Tobon AA, et al (1997) Primary human prostate cancer cells harboring p53 mutations are clonally expanded in metastases. Clin Cancer Res 3: 1389-1397.

62. Swanson G (2006) Management of locally advanced prostate cancer: Past, present, future. J Urol 176: S34-S41.

63. Swanson GP, Faulkner J, Smalley SR, Noble MJ, Stephens RL, et al. (2006) Locally advanced prostate cancer treated with concomitant radiation and 5-fluorouracil: Southwest oncology group study 9024. J Urol 176: 548-553.

64. Swanson GP, Thompson IM, Basler J (2006) Treatment options in lymph nodepositive prostate cancer. Cancer 106: 2531-2539.

65. Thompson IM, Tangen CM, Paradelo J, Lucia MS, Miller G, et al. (2006) Adjuvant radiotherapy for pathologically advanced prostate cancer. JAMA 296: 2329-2335.

66. Thompson IM, Thrasher JB, Aus G, Burnett AL, Canby-Hagino ED, et al. (2007) Guideline for the management of clinically localized prostate cancer: 2007 update. J Urol 177: 2106-2131.

67. Yallapu MM, Maher DM, Sundram V, Bell MC, Jaggi M, et al. (2010) Curcumin induces chemo/radio-sensitization in ovarian cancer cells and curcumin nanoparticles inhibit ovarian cancer cell growth. J Ovarian Res 3: 11.

68. Yu S, Shen G, Khor TO, Kim JH, Kong AT (2008) Curcumin inhibits Akt/ mammalian target of rapamycin signaling through protein phosphatasedependent mechanism. Mol Cancer Ther 7: 2609-2620

69. Zhang AL, Russell PL, Knittel T, Milross C (2007) Paclitaxel enhanced radiation sensitization for the suppression of human prostate cancer tumor growth via a p53 independent pathway. Prostate 67: 1630-1640. 